\title{
KUALITAS LIMBAH SERBUK GERGAJI UNTUK ARANG YANG DIPEROLEH DENGAN METODE PIROLISIS LAMBAT
}

\author{
Irhamni Nuhardin \\ Program Studi Teknik Kimia, Sekolah Tinggi Teknologi Industri Bontang \\ Jl. Brigjen Katamso No. 40, Bontang (75313), Telp. 0548 20369. Faks. 054821512 \\ E-mail : irhamni.in@gmail.com
}

\begin{abstract}
Abstrak
Limbah serbuk gergaji kayu menimbulkan masalah dalam penanganannya, yaitu dibiarkan membusuk, ditumpuk, dan dibakar yang kesemuanya berdampak negatif terhadap lingkungan. Oleh karena itu, penanggulangannya perlu dipikirkan. Salah satu jalan yang dapat ditempuh adalah dengan memanfaatkannya menjadi produk yang bernilai tambah dengan teknologi aplikatif dan kerakyatan, sehingga hasilnya mudah disosialisasikan kepada masyarakat. Penelitian ini dilakukan dengan tujuan untuk: (1) Mengetahui suhu optimum berdasarkan nilai kalor. (2) Mengetahui waktu penahanan temperatur akhir yang optimum berdasarkan nilai kalor. Bahan utama yang digunakan dalam penelitian ini adalah limbah biomassa berupa serbuk gergaji kayu bayam yang diambil dari salah satu usaha meubel yang mengelola kayu bayam. Penelitian ini dilakukan dengan menggunakan alat pirolisis yang telah didesain secara khusus untuk menghasilkan data kuantitatif dan kualitatif dengan berbagai variabel suhu yaitu $350^{\circ} \mathrm{C}, 400^{\circ} \mathrm{C}, 450^{\circ} \mathrm{C}$ dan $500^{\circ} \mathrm{C}$. Variabel waktu tinggal yaitu, 60 menit, 90 menit, 120 menit, 150 menit dan 180 menit. Variabel ukuran digunakan menggunakan ukuran yang lolos pada ayakan $3 / 8$ in dan tertahan pada ukuran $1 / 4$ in. Parameter yang dianalisa yaitu analisa proximate dan nilai kalor. Hasil penelitian ini menunjukkan bahwa: (1) Suhu optimum yang baik digunakan pada proses pembuatan arang menggunakan limbah serbuk gergaji adalah pada suhu $350^{\circ} \mathrm{C}$ dengan nilai kalor yang dihasilkan yaitu $7.121 \mathrm{Cal} / \mathrm{gr}$. Waktu penahanan yang optimum digunakan pada pembuatan arang (charcoal) dengan menggunakan limbah serbuk gergaji yaitu pada waktu penahanan selama 90 menit dengan nilai kalor yang dihasilkan $7.050 \mathrm{Cal} / \mathrm{gr}$.
\end{abstract}

Kata Kunci : Arang, pirolisis, serbuk gergaji.

\section{PENDAHULUAN}

Masalah energi tidak lepas dari kehidupan manusia. Pertambahan jumlah penduduk, peningkatan pola hidup manusia dan semakin banyaknya industri yang berkembang mengakibatkan permintaan akan kebutuhan energi terus meningkat, sedangkan ketersediaan cadangan energi semakin menipis. Hal ini berdampak pada meningkatnya harga jual bahan bakar minyak dunia khususnya minyak tanah di Indonesia. Oleh karena itu, diperlukan bahan bakar alternatif yang murah dan ramah lingkungan sebagai pengganti minyak tanah untuk industri kecil dan rumah tangga [8].
Industri meubel kayu merupakan salah satu industri yang banyak terdapat di Indonesia. Dalam menjalankan proses usaha tersebut industri meubel menghasilkan limbah yang jarang sekali termanfaatkan oleh mayoritas orang, yaitu serbuk gergaji. Berdasarkan data BPS tahun 2013, produksi serbuk gergaji kayu di Indonesia sebesar $1.217 .868 \mathrm{~m}^{3}$ dengan densitas $600 \mathrm{~kg} / \mathrm{m}^{3}$ maka didapatkan 730.720 .800 ton. Jika dari kayu yang tersedia tedapat $40 \%$ yang menjadi limbah serbuk gergaji, maka akan didapat potensi pembuatan briket sebesar 292.288.320 ton/tahun.

Limbah serbuk gergaji kayu menimbulkan masalah dalam penanganannya, yaitu dibiarkan membusuk, ditumpuk, dan dibakar yang kesemuanya 
berdampak negatif terhadap lingkungan. Oleh karena itu, penanggulangannya perlu dipikirkan. Salah satu jalan yang dapat ditempuh adalah memanfaatkannya menjadi produk yang bernilai tambah dengan teknologi aplikatif dan kerakyatan, sehingga hasilnya mudah disosialisasikan kepada masyarakat [3].

Seiring dengan berkembangnya ilmu pengetahuan maka dibutuhkan adanya teknologi yang dapat mengolah serbuk gergaji menjadi salah satu produk yang berguna untuk masyarakat yaitu dengan membuat asap cair dan arang yang merupakan bahan baku pembuatan briket dengan menggunakan proses pirolisis. Penelitian ini dilakukan dengan harapan agar masyarakat dapat mengetahui tentang salah satu manfaat dari serbuk gergaji yang merupakan limbah tersebut menjadi salah satu bahan aditif dalam membuat sumber energi berupa arang untuk pembuatan briket, dan hasil samping yang berupa asap cair yang dapat digunakan sebagai pestisida.

\section{TINJAUAN PUSTAKA}

Kelangkaan dan kenaikan harga minyak akan terus terjadi karena sifatnya yang non renewable. Hal ini harus segera diimbangi dengan penyediaan sumber energi alternatif yang rewenable, melimpah jumlahnya, dan murah harganya sehingga terjangkau oleh masyarakat luas. Disamping untuk mendapatkan sumber energi baru, usaha yang terus-menerus dilakukan dalam rangka mengurangi emisi $\mathrm{CO}_{2}$ guna mencegah terjadinya pemanasan global, hal telah mendorong penggunaan energi biomassa sebagai pengganti energi bahan bakar posil seperti batubara dan minyak bumi [4].

Persediaan minyak atau gas bumi sangat terbatas dan tidak dapat diperbaharui. Oleh karena itu peran inovasi teknologi untuk mengatasi krisis energi tersebut sangat diperlukan, yaitu membuat bahan bakar alternatif sangat diperlukan. Untuk membuat bahan bakar alternatif yang murah dan mudah dibuat dan mempunyai nilai kalor yang tinggi. Bahan bakar alternatif tersebut diharapkan dapat memenuhi kebutuhan bahan bakar masyarakat dan khususnya industri kecil, selain itu bahan baku yang digunakan dapat meningkatkan efisiensi pengolahan hasil hutan serta memaksimalkan pemanfaatan kayu dan limbah biomassa [3].

1. Biomassa

Biomassa terdiri atas beberapa komponen yaitu kandungan air (moisture content), zat mudah menguap (volatile matter), karbon terikat (fixed carbon), dan abu (ash). Mekanisme pembakaran biomassa terdiri dari tiga tahap yaitu pengeringan (drying), devolatilisasi (devolatilization), dan pembakaran arang (char combustion). Proses pengeringan akan menghilangkan moisture, devolatilisasi yang merupakan tahapan pirolisis akan melepaskan volatile, dan pembakaran arang yang merupakan tahapan reaksi antara karbon dan oksigen, akan melepaskan kalor. Laju pembakaran arang tergantung pada laju reaksi antara karbon dan oksigen pada permukaan dan laju difusi oksigen pada lapis batas dan bagian dalam dari arang. Reaksi permukaan terutama membentuk CO. Diluar partikel, $\mathrm{CO}$ akan bereaksi lebih lanjut membentuk $\mathrm{CO}_{2}$. Pembakaran akan menyisakan material berupa abu [5].

\section{Kayu}

Kayu adalah material yang dapat terurai dan dapat di daur ulang secara sempurna. Dengan demikian, kayu merupakan material bahan bangunan yang ramah lingkungan. Produksi total kayu gergajian Indonesia mencapai 2,6 juta $\mathrm{m}^{3} /$ tahun. Dengan asumsi bahwa jumlah limbah yang terbentuk 54,24\% dari produksi total sehingga di hasilkan 1,4 juta $\mathrm{m}^{3} /$ tahun dan angka ini cukup besar karena mencapai sekitar separuh dari produksi kayu gergajian [3].

3. Pirolisis

Salah satu teknologi alternatif yang dikembangkan pada beberapa bidang dalam kimia yaitu pirolisis biomassa. Salah satunya mengisolasi senyawa kimia yang kemudian dapat dikonversi menjadi sumber energi hidrokarbon alternatif [6]. 
Berbagai variabel yang berpengaruh dalam proses pirolisis antara lain suhu, waktu, dan kadar air bahan Jumlah produk yang dihasilkan berbanding lurus dengan kenaikan suhu serta lama proses berlangsung. Sedangkan padatan atau arang yang tertinggal dalam retort akan semakin sedikit dengan adanya kenaikan suhu dan waktu proses [9].

Pirolisis adalah suatu proses dekomposisi kimia dengan bahan organik melalui proses pemanasan tanpa atau sedikit oksigen atau reagen lainnya, dimana material mentah akan mengalami pemecahan struktur kimia menjadi fase gas. Bahan yang digunakan adalah biomassa (bahan organik) yang hasil produksi dari mahluk hidup. Penelitian-penelitian mengenai pirolisis sekarang ini mengarah kepada usaha-usaha pencarian bahan bakar alternatif dari biomassa. Pembuatan bio-oil dari pirolisis serbuk gergaji menggunakan fluidized bed reactor. Proses pirolisis dijalankan dengan katalis maupun tanpa katalis. Hasil penelitian menunjukkan bahwa proses pirolisis memakai katalis akan menghasilkan bio-oil yang lebih baik kualitasnya [2].

Pirolisis biomassa pada suhu tinggi memungkinkan konversi bahan organik (selulosa, hemiselulosa dan lignin) menjadi gas sintetik $\left(\mathrm{CO}, \mathrm{H}_{2}, \mathrm{CO}_{2}\right.$, gas hidrokarbon, dll.) dan abu yang mengandung karbon padat. Selain itu, emisi karbon secara keseluruhan dari biomassa tidak menimbulkan efek rumah kaca karena nilai emisi karbon dari biomassa sama dengan nilai karbon tetap pada fotosintesis tanaman [7].

\section{METODE PENELITIAN}

\section{Bahan}

Bahan yang digunakan dalam penelitian ini adalah limbah biomassa serbuk gergaji kayu bayam dengan ukuran $1 / 4-3 / 8$ in yang diukur menggunakan ayakan.
Alat

Penelitian ini dilaksanakan dengan menggunakan satu unit alat pirolisis seperti ditunjukkan pada Gambar 1.

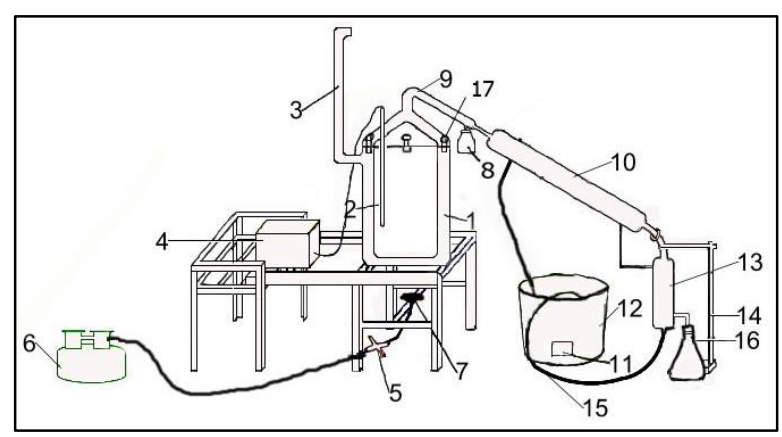

Gambar 1. Alat pirolisis

Keterangan Gambar 1:

1. Reaktor pirolisis

2. Pipa pengontrol suhu

3. Pipa cerobong asap

4. Termokopel

5. Pengontrol nyala api

6. Tabung gas

7. Tungku Pembakaran gas

8. Penampungan tar

9. Penutup reaktor pirolisis

10. Kondensor

11. Pompa

12. Water tank

13. Katup pengeluaran asap

14. Tiang Penyangga

15. Selang

16. Penampung asap cair

17. Skrup

\section{Prosedur Penelitian}

\section{Tahap Persiapan Bahan Baku}

Persiapan bahan baku limbah serbuk gergaji kayu bayam meliputi beberapa tahapan yaitu ukuran 1/4 - 3/8 in, kemudian serbuk gergaji tersebut dijemur di bawah sinar matahari selama 2-3 hari untuk mengurangi kadar air.

\section{Pelaksanaan Penelitian}

Serbuk gergaji ditimbang sebanyak 35 ons dan dimasukkan ke dalam reaktor pirolisis. Temperatur diatur sesuai dengan variabel yang telah ditentukan yaitu mulai suhu $350^{\circ} \mathrm{C}, 400^{\circ} \mathrm{C}, 450^{\circ} \mathrm{C}$ dan $500^{\circ} \mathrm{C}$, dengan waktu penahanan selama 60 menit setelah suhu yang ditentukan tercapai, arang 
yang didapatkan ditimbang dan dianilisis proximate-nya, serta diuji nilai kalornya guna penentuan energi yield proses pirolisis. Prosedur tersebut di atas kemudian digunakan untuk variabel selanjutnya.

\section{Variabel Penelitian}

Suhu proses pirolisis yang digunakan yaitu $350^{\circ} \mathrm{C}, 400^{\circ} \mathrm{C}, 450^{\circ} \mathrm{C}$ dan $500^{\circ} \mathrm{C}$. Waktu penahanan temperatur akhir yang digunakan yaitu 60 menit, 90 menit, 120 menit, 150 menit, dan 180 menit.

\section{HASIL DAN PEMBAHASAN}

\section{Pengaruh Suhu Terhadap Proses Pirolisis Lambat Limbah Serbuk Gergaji Kayu Bayam}

Berat serbuk gergaji yang di masukkan ke dalam alat pirolisis adalah tetap yaitu sebanyak 35 ons untuk semua variabel suhu, waktu tinggal yang digunakan adalah selama 60 menit dan jenis ukuran bahan yang digunakan adalah ukuran $1 / 4-3 / 8$ in, sehingga diperoleh hasil seperti pada Gambar 2.

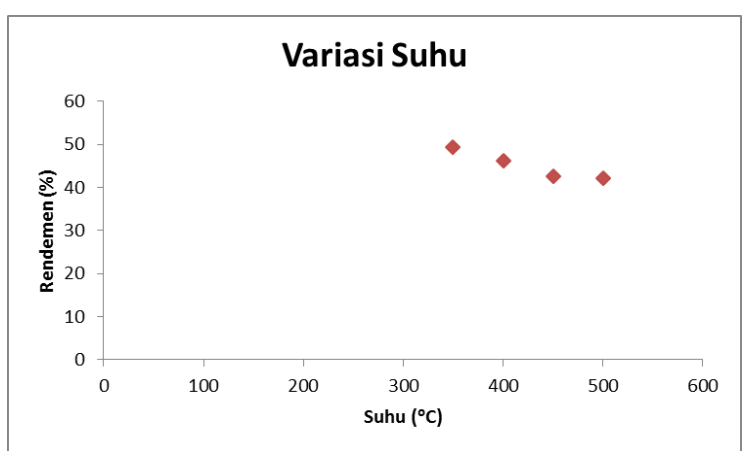

Gambar 2. Grafik hubungan temperatur dengan rendemen pada proses pirolisis serbuk gergaji kayu bayam

Berdasarkan Gambar 2 dapat dilihat bahwa terjadi penurunan berat serbuk gergaji kayu bayam pada saat setelah proses pirolisis. Semakin tinggi temperatur pirolisis yang digunakan maka berat arang dari serbuk gergaji kayu bayam semakin menurun. Rendemen merupakan persentase perbandingan berat bagian bahan yang dapat dimanfaatkan dengan total bahan. Hasil rendemen serbuk gergaji kayu bayam pada temperatur $350^{\circ} \mathrm{C}-450^{\circ} \mathrm{C}$ yaitu antara 42 $49 \%$, dengan rendemen tertinggi terjadi pada suhu $350^{\circ} \mathrm{C}$ yaitu $49 \%$ dan rendemen terkecil terjadi pada suhu $480-500^{\circ} \mathrm{C}$ yaitu $42 \%$. Rendahnya rendemen bukan penentu baik buruknya arang yang dihasilkan, begitupun tingginya rendemen tidak menentukan bahwa arang serbuk gergaji tersebut baik untuk dimanfaatkan sebagai bahan baku briket. Menurut Adinata, peningkatan suhu mempengaruhi rendemen produk pirolisis yang dihasilkan. Bila waktu pemanasan diperpanjang atau ditingkatkan maka reaksi pirolisis makin sempurna sehingga hasil arang semakin berkurang, dimana semakin lama waktu yang digunakan akan menyebabkan bahan menjadi arang yang kemudian berubah menjadi abu sehingga menyebabkan berkurangnya berat pada arang.[1]

Pada pembuatan arang dari bahan limbah serbuk gergaji kayu bayam yang dilakukan dengan cara pirolisis menghasilkan produk yang kemudian di analisa di laboratorium analisis, adapun yang di analisa yaitu kadar air (mousture), kadar abu (ash), volatile matter (VM), fixed carbon (FC), nilai kalor, dan Sulfur.

\section{Analisa Proximate}

\section{a) Kadar Air (Mousture)}

Kadar air (mousture) pada penelitian ini tidak stabil. Pada saat sebelum proses pirolisis dilakukan nilai kadar air pada limbah serbuk gergaji kayu bayam adalah $10,82 \%$, setelah melalui proses pirolisis kadar air pada arang limbah serbuk gergaji menjadi menurun. Pada suhu $350^{\circ} \mathrm{C}$ kadar air yang diperoleh menurun menjadi $2,97 \%$, pada suhu $400^{\circ} \mathrm{C}$ kadar air meningkat menjadi sekitar $3,48 \%$ dan pada suhu $450^{\circ} \mathrm{C}$ kadar air meningkat lagi menjadi 4,22 \% tetapi pada suhu $500^{\circ} \mathrm{C}$ kadar air mengalami penurunan kembali.

Faktor yang mempengaruhi kadar air adalah suhu dan cara penyimpanan. Hal ini disebabkan karena suhu akan menyebabkan kelembaban udara yang berdampak pada kadar air, begitu juga dengan cara penyimpanan akan mempengaruhi cara penyerapan. Dari data di atas menunjukkan bahwa kadar air minimum pada arang 
limbah serbuk gergaji kayu bayam yang telah dipirolisis adalah pada suhu karbonisasi $350^{\circ} \mathrm{C}$, sedangkan kadar air maksimum pada arang limbah serbuk gergaji kayu bayam yang telah dipirolisis adalah pada suhu $450^{\circ} \mathrm{C}$.

\section{b) Kadar Abu (Ash)}

Abu adalah bahan yang tersisa apabila biomassa dipanaskan hingga berat konstan. Salah satu unsur utama yang terkandung pada abu adalah silika dan pengaruhnya kurang baik terhadap nilai kalor yang dihasilkan. Kadar abu yang dihasilkan pada penelitian ini tidak stabil. Pada suhu $350^{\circ} \mathrm{C}$ kadar abu menurun akan tetapi pada suhu $400-500^{\circ} \mathrm{C}$ kadar abu menjadi meningkat. Dari data di atas terlihat bahwa kadar abu terendah terdapat pada suhu $400^{\circ} \mathrm{C}$ yaitu $1,67 \%$, sedangkan kadar abu tertinggi yaitu pada suhu $500^{\circ} \mathrm{C}$ yaitu $2,48 \%$.

\section{c) Zat Terbang (Volatile Matter)}

Zat terbang adalah zat yang dapat menguap sebagai hasil dekomposisi senyawa-senyawa yang masih terdapat dalam arang limbah serbuk gergaji selain air. Pada penelitian ini zat terbang yang dihasilkan pada saat sebelum pirolisis sangat tinggi yaitu $62,58 \%$ sedangkan pada saat setelah proses pirolisis zat terbang mengalami penurunan. Pada suhu 350 $450^{\circ} \mathrm{C}$ zat terbang yang terdapat pada serbuk gergaji terus menurun yaitu dari 36,14\% menjadi $28,74 \%$, namun pada suhu $500^{\circ} \mathrm{C}$ mengalami peningkatan menjadi $65,04 \%$

Kandungan kadar zat menguap yang tinggi di dalam briket akan menyebabkan asap yang lebih banyak pada saat briket di nyalakan. Kandungan asap yang tinggi disebabkan karena adanya reaksi antara karbon monoksida (CO) dengan turunan alkohol. Tinggi rendahnya kadar zat menguap arang limbah serbuk gergaji kayu bayam dihasilkan karena dipengaruhi oleh jenis bahan baku, sehingga perbedaan jenis bahan baku berpengaruh nyata terhadap zat menguap briket arang. Sehingga dapat dikatakan bahwa semakin tinggi suhu pada proses pirolisis limbah serbuk gergaji kayu bayam maka semakin rendah kadar zat terbang yang terkandung dalam serbuk gergaji pirolisis.

\section{d) Fixed Carbon}

Fixed Carbon adalah persen berat setelah dikoreksi dengan nilai kandungan moisture, ash, dan volatile matter. Pada penelitian ini diperoleh hasil analisa yaitu pada saat sebelum pirolisis nilai fixed Carbon adalah 26,61 \%, akan tetapi setelah proses pirolisis maka nilai fixed carbon menjadi meningkat yaitu pada suhu $350^{\circ} \mathrm{C}$ $400^{\circ} \mathrm{C}$ namun pada suhu $450^{\circ} \mathrm{C}-500^{\circ} \mathrm{C}$ nilai fixed carbon mengalami penurunan yaitu menjadi $65,16 \%$ dan $65,04 \%$. Sehingga dapat dikatakan bahwa semakin tinggi suhu pada proses pirolisis serbuk gergaji kayu bayam maka semakin tinggi nilai fixed carbon yang dihasilkan hingga mencapai suhu tertentu kemudian kembali mengalami penurunan.

Fixed karbon di dalam arang limbah serbuk gergaji dipengaruhi oleh nilai kadar abu dan kadar zat menguap. Fixed carbonnya akan tinggi apabila ash dan volatile matter arang limbah serbuk gergaji tersebut rendah. Semakin tinggi fixed carbon pada arang serbuk gergaji maka menandakan arang tersebut adalah arang yang baik.

\section{e) Nilai Kalor}

Nilai kalor suatu bahan sangat menentukan kualitas suatu briket. Semakin tinggi nilai kalor pada briket maka semakin baik pula kualitas arang yang dihasilkan. Pada penelitian ini mengalami peningkatan nilai kalor, untuk hasil yang lebih jelas dapat dilihat pada Gambar 3.

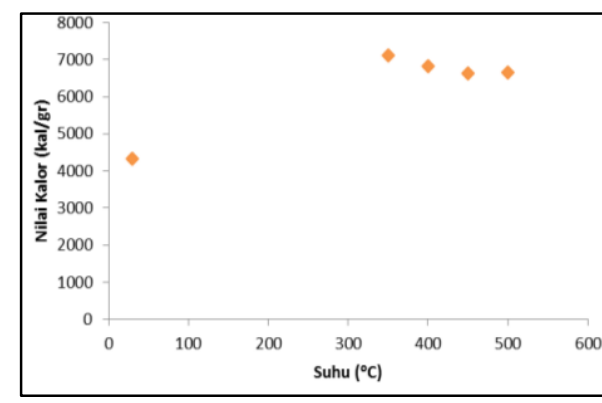

Gambar 3. Grafik peningkatan Nilai kalor pada proses pirolisis serbuk gergaji kayu bayam dengan variabel suhu 
Berdasarkan grafik di atas dapat dilihat bahwa peningkatan nilai kalor sebelum pirolisis dan setelah pirolisis sangat tinggi. Pada saat setelah proses pirolisis nilai kalor yang dihasilkan pada suhu $350^{\circ} \mathrm{C}$ cukup tinggi yaitu $7121 \mathrm{Cal} / \mathrm{gr}$, sedangkan pada suhu $400^{\circ} \mathrm{C}$ nilai kalor yang diperoleh yaitu $6821 \mathrm{Cal} / \mathrm{gr}$. Sedangkan pada suhu $450^{\circ} \mathrm{C}$ dan $500^{\circ} \mathrm{C}$ mengalami penurunan nilai kalor yaitu $6620 \mathrm{Cal} / \mathrm{gr}$ dan 6647 $\mathrm{Cal} /$ gr. Sehingga dapat dikatakan bahwa pada suhu $350^{\circ} \mathrm{C}$ merupakan puncak nilai kalor tertinggi pada variabel suhu.

\section{f) Sulfur}

Hasil analisa kadar Sulfur untuk semua sampel pada proses pirolisis serbuk gergaji kayu bayam semua tergolong rendah. Kadar Sulfur tertinggi yaitu 0,2820 $\%$ sedangkan kadar Sulfur yang rendah yaitu 0,0763\%, kondisi ini menunjukkan hasil pirolisis dari serbuk gergaji kayu bayam tidak menimbulkan dampak pencemaran gas Sulfur jika digunakan sebagai bahan bakar.

\section{Pengaruh Waktu Terhadap Proses Pirolisis Lambat Limbah Serbuk Gergaji Kayu Bayam}

Berat serbuk gergaji yang dimasukkan ke dalam alat pirolisis adalah tetap yaitu $1 \mathrm{~kg}$ untuk semua variabel waktu, suhu yang digunakan adalah $400^{\circ} \mathrm{C}$ dan jenis ukuran bahan yang digunakan adalah ukuran 1/4 - 3/8 in, sehingga diperoleh hasil seperti pada data yang diolah pada Gambar 4 .

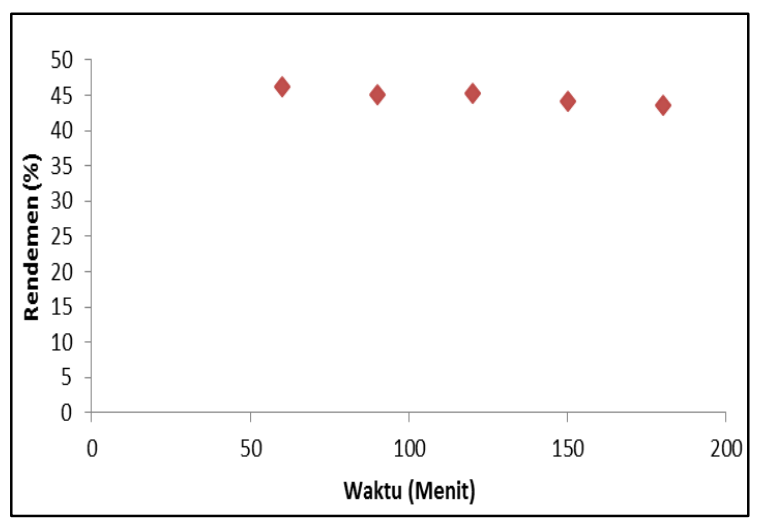

Gambar 4. Grafik Hubungan waktu dengan rendemen pada proses pirolisis serbuk gergaji kayu bayam
Berdasarkan Gambar 4 di atas diperoleh data penurunan rendemen pada proses pirolisis dengan variabel waktu. Pada Gambar 4 dilihat semakin lama waktu tinggal yang digunakan pada proses pirolisis maka semakin berkurang rendemen dari arang limbah serbuk gergaji. Berdasarkan hasil analisis dihasilkan rendemen tertinggi yaitu pada waktu tinggal 60 menit. Sedangkan rendemen yang terendah adalah pada waktu tinggal selama 150 menit dan 180 menit yaitu $44 \%$. Sehingga dapat dikatakan bahwa lama waktu pirolisis mempengaruhi rendemen produk pirolisis yaitu semakin lama waktu yang digunakan maka semakin rendah rendemen produk yang dihasilkan.

\section{Analisa Proximate}

\section{a) Kadar Air (Mousture)}

Kadar air (mousture) pada penelitian ini dapat dikatakan stabil karena kadar air rata-rata pada 3,4 \%. Kadar air tertinggi pada hasil karbonisasi serbuk gergaji kayu bayam yaitu terdapat pada waktu tinggal selama 120 menit yaitu 3,61\%, sedangkan kadar air terendah yaitu pada waktu tinggal selama 90 menit yaitu 3,37 \%. Faktor yang mempengaruhi kadar air adalah suhu dan cara penyimpanan. Hal ini disebabkan karena suhu akan menyebabkan kelembaban udara yang berdampak pada kadar air, begitu juga dengan cara penyimpanan akan mempengaruhi cara penyerapan.

\section{b) Kadar Abu (Ash)}

Kadar abu yang dihasilkan pada penelitian ini dapat dikatakan stabil karena rata-rata kadar abu yang dihasilkan adalah $1,73 \%$. Kadar abu pada proses pirolisis dengan variabel waktu ini dihasilkan nilai maksimal yaitu pada waktu tinggal selama 180 menit yaitu $1,79 \%$ dan waktu minimal waktu tinggal selama 120 menit yaitu sebanyak 1,64\%.

\section{c) Zat Terbang (Volatile Matter)}

Hasil analisa zat terbang (volatile matter) untuk variabel waktu tinggal pada produk pirolisis serbuk gergaji kayu bayam yang dihasilkan bervariasi. Berdasarkan 
hasil analisa dihasilkan zat terbang tertinggi yaitu pada waktu tinggal selama 120 menit yaitu $33,36 \%$. Sedangkan untuk zat terbang terendah terdapat pada waktu tinggal selama 180 menit yaitu 26,35 \%.

\section{d) Fixed Carbon}

Fixed Carbon adalah persen berat setelah dikoreksi dengan nilai kandungan moisture, ash, dan volatile matter. Pada penelitian ini diperoleh hasil analisa yaitu pada waktu tinggal 60 menit mengalami peningkatan. Pada waktu tinggal 90-150 menit mengalami penurunan, kemudian pada waktu tinggal 180 menit nilai fixed carbon mengalami kenaikan. Sehingga fixed carbon tertinggi terletak pada waktu tinggal selama 180 menit yaitu $68,47 \%$ dan fixed carbon terendah terletak pada waktu tinggal 120 menit yaitu 61,39\%. Fixed carbonnya akan tinggi apabila ash dan volatile matter rendah. Semakin tinggi fixed carbon pada arang serbuk gergaji maka arang yang dihasilkan semakin baik.

\section{e) Nilai Kalor}

Berdasarkan hasil analisa yang dilakukan, maka nilai kalor yang dihasilkan pada proses pirolisis dengan menggunakan variabel waktu diperoleh hasil seperti yang terdapat pada Gambar 5.

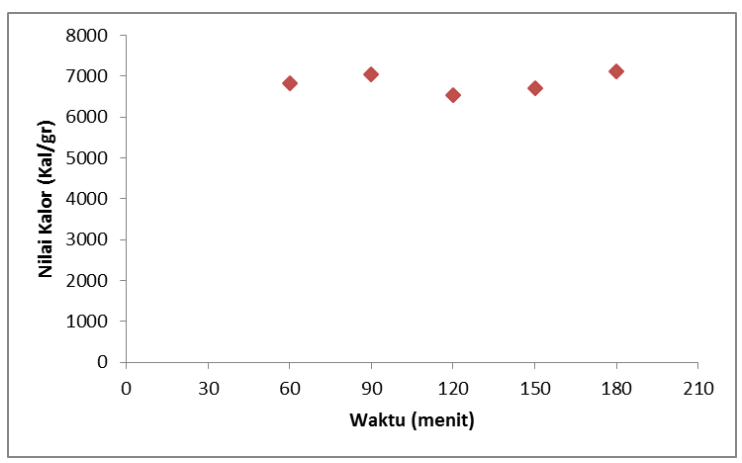

Gambar 5. Grafik peningkatan Nilai kalor pada proses pirolisis serbuk gergaji kayu

bayam dengan variabel waktu

Dari Gambar 5 dapat dilihat bahwa untuk hasil analisis nilai kalor produk dari proses pirolisis dengan menggunakan variabel waktu tinggal yaitu pada waktu tinggal 60 - 90 menit nilai kalor terus meningkat. Namun pada waktu tinggal selama 120 menit mengalami penurunan nilai kalor kemudian mengalami peningkatan pada waktu tinggal selama 150 menit dan 180 menit. Nilai kalor tertinggi terdapat pada waktu tinggal selama 180 menit yaitu $7121 \mathrm{Cal} / \mathrm{gr}$, dan waktu tinggal terendah terdapat pada waktu tinggal selama 150 menit yaitu dengan nilai kalor 6534 $\mathrm{Cal} / \mathrm{gr}$.

Semakin lama waktu pembakaran maka nilai rata-rata nilai kalor yang dihasilkan semakin besar. Hal ini disebabkan karena pembentukan arang dalam proses pirolisis yang berlangsung lebih lama dan merata, sehingga proses penguraian biomassa menjadi lebih sempurna. Namun kecenderungan peningkatan nilai kalor berbanding lurus dengan waktu tidak terjadi pada waktu 120 menit. Hal ini disebabkan karena pada suhu $400^{\circ} \mathrm{C}$ telah tercapai nilai kalor optimal untuk waktu 120 menit. Sehingga tidak sama dengan waktu 60 dan 90 menit yang terus mengalami kenaikan nilai kalor. Terjadinya penurunan nilai kalor pada waktu tinggal 120 menit dapat di karenakan kandungan air sebelum proses pirolisis berbeda.

\section{f) Sulfur}

Hasil analisa kadar Sulfur pada variabel waktu ini bervariasi. Kadar Sulfur tertinggi terdapat pada waktu tinggal selama 120 menit yaitu 0,3093\% dan mengalami penurunan pada waktu tinggal 120 menit yaitu 0,2699 \%. Kadar Sulfur terendah terdapat pada waktu tinggal 180 menit yaitu $0,1609 \%$, sedangkan kadar Sulfur tertinggi terdapat pada waktu tinggal 120 menit. Pada saat arang serbuk gergaji pirolisis digunakan dalam proses pembakaran, kandungan Sulfur tersebut tidak menimbulkan pencemaran gas Sulfur terhadap lingkungan.

\section{KESIMPULAN}

Berdasarkan hasil dari penelitian maka dapat disimpulkan bahwa:

1. Suhu optimum yang baik digunakan pada proses pembuatan arang menggunakan limbah serbuk gergaji adalah pada suhu 
$350{ }^{\circ} \mathrm{C}$ dengan nilai kalor yang dihasilkan yaitu $7.121 \mathrm{Cal} / \mathrm{gr}$.

2. Waktu penahanan yang optimum digunakan pada pembuatan arang (charcoal) dengan menggunakan limbah serbuk gergaji yaitu pada waktu penahanan selama 90 menit dengan nilai kalor yang dihasilkan $7050 \mathrm{Cal} / \mathrm{gr}$.

\section{REFERENSI}

[1]. Adinata, M. R. (2013). Pemanfaatan Limbah kilit Pisang Sebagai Karbon Aktif. Jawa Timur: FTI-UPN Jawa Timur.

[2]. Bajus, M. (2011). Thermal Cracking of Mixtures of Plastics and Woody Material. Petrolium Coal, 1-7.

[3]. Billah, M. (2009). Bahan Bakar Alternatif padat (BBAP) Serbuk Gergaji. Surabaya: UPN Press.

[4]. Dewi, L. A. (2011). Pengembangan Serbuk Gergaji Menjadi BioOil Menggunakan Pirolisis. Semarang: Universitas Diponegoro.

[5]. Hardianto, L., \& Yunianta. (2015). Pengaruh Asap Cair erhadap Sifat Kimia dan Organoleptik Ikan Tongkol (Euthynnus affinis). Jurnal Pangan dan Agroindustri, 1356-1366.

[6]. Pramanto, A. C. (2013). Studi Kuat Tekan, Kuat Geser dan Kuat Lekat Campuran Amplasan Kayu Jati dengan Perekat Resin dan Hardener Sebagai Bahan Perbaikan Kayu. Surakarta: Universitas Sebelas Maret.

[7]. Rashid, A.R.M. (2014). Reduction of Low Grade Iron Ore Pellet Using Palm Kernel Shell. Renewable Energy 63. 617623.
[8]. Setiawan, A., Andrio, O., \& Coniwanti, P. (2012). Pengaruh Komposisi Pembuatan Biobriket Dari Camuran Kulit Kacang dan Serbuk Gergaji Terhadap Nilai Pembakaran. Jurnak Teknik Kimia, 9-16.

[9]. Sumarni, \& Purwanti, A. (2008). Kinetika Reaksi Pirolisis Plastik Low Density Poliethylene (LDPE). Jurnal Teknologi, 1, 135-140. 